\title{
The Study of Local Politics Effects on Capital Spending Allocation of Regional Government (Case Study at 456 Districts / City in Indonesia)
}

\author{
Raden Yudi Prawira Anjaya \\ Student Postgraduate \\ Universitas Andalas \\ Padang, Indonesia \\ radenyudi@ymail.com
}

\begin{abstract}
The issue of this study was to examine the effect of political closeness between the executivelegislative and the period of political office of regional heads on changes in the allocation of local government capital spending in Indonesia. Data of samples were collected from 456 districts/cities in Indonesia from 2010 to 2014, using Panel Least Square method using fixed-effect model. From the results of the research shows that political proximity significantly affects the change of capital expenditure allocation and has a positive coefficient which means that the closer the political relationship between the legislature and the executive will lead to greater allocation of regional capital expenditure and the further the relationship between the legislature and the executive will encourage the allocation of expenditure lower capital, while the period of political office has no significant effect on changes in local government capital expenditures.
\end{abstract}

Keywords: spend funding; capital government; local political.

\section{INTRODUCTION.}

Regional funding spending is an important instrument in stimulating the local economy. The amount of local revenue allocation that can be used for local expenditure will encourage faster economic growth. Adjustment process for the better financial condition can be done by changing the structure of spending. The policy on spending allocation is a tool in determining the direction of fiscal policy.

An interesting phenomenon in Indonesia that shows how budget politics is used to accommodate the political and economic interests of political officials of legislative members and regional heads. Exploiting the budget for political purposes can be done through a series of budget politics policies, first,

By increasing the amount of local government spending. The country is a current trend for every local government to increase the amount of local spending from year to year (Drazen 2005; Sole 2006;
Faucault 2008; Dash 2012; Kaushik 2012). Of course, efforts to increase spending can be said to be good if done based on the interests of the community but on the opposite, if done for the benefit of particular parties or groups then it can lead to inefficiency and deficit budget.

Some political variables that will affect changes in local government expenditure structure are political closeness and period of political office of a regional head. The closeness between the executive namely the chairman of the region with the legislative members, especially those from the party winning the election will certainly affect the process of preparing the regional budget. The stronger the political closeness between the executive and the legislature, the easier it will be in preparing the regional budgets for the same political interests and purposes, and vice versa if the weaker the closeness between the executive and the legislature will cause the budgeting process to cause a debate to unite political goals and interests different before the deal.

The term of office referred to is the period of office of the regional head who leads an area known as the regent or mayor. A regional head elected through the election process may hold a maximum of two periods. In the last years of the first term, the head of the region who wishes to run again will usually "spread the good" in the eyes of his potential voters in the hope of winning the most votes. Various attempts are made by petahana to attract voters, one of them by utilizing local government budget, for example by enlarging allocation of social assistance expenditure, grant expenditure for certain groups/community groups, growing personal cost by providing various local allowances to gain sympathy from the apparatus civil state.

While in the second period, where peoples can't nominate again, it is allegedly likely to increase the capital expenditure for infrastructure development either on the grounds of the interests of the local community as well as the reasons that are hidden 
funding heads of regions to enrich themselves or groups.

It is still a question of whether or not strong or weak proximity between the executive and legislative and the period of office of the regional head will affect the allocation of local government spending to the district and city levels in Indonesia. This research seeks to explain the influence of these political variables on changes in regional capital expenditures.

\section{LITERATURE REVIEW.}

Government majority with one party is the most dominant form of government because the government controls parliament vis a vis opposition and faces less significant internal conflicts regarding budgeting policy. Meanwhile, coalition governments are facing more internal conflicts in budgetary policies. The logic is that reducing the budget deficit can be regarded as a public good in a coalition government. Each party wants to consume public goods (from deficit reduction) without paying them by cutting expenses that benefit the group. The more parties involved in the coalition, the less likely the coordination in the budget deficit will be successful.

On the other hand, Allesina and Drazen (1991) used game theory models to explain how government budget cuts and tax increases for stabilization are difficult to achieve. A tax increase which means putting more burdens on a community will be challenged by the way the community groups try to influence the government's decision to delay the decision or to avoid it even with a sacrifice. As long as the sacrifice is still lower than the tax burden, the community group will continue to influence the government to delay the decision to increase taxes (thus avoiding community groups from the tax burden).

Galli and Rossi (2002), identified four phases of the electoral cycle, namely: election year (T_0), the year after the general election ( $\left.T_{-} 1\right)$, mid of the term of office year ( $\left.T_{-} 2\right)$ and the year before the election (T_3). Each variable dummy shows the idea that the government makes some temporary asymmetric information and tries to give a 'competence' signal before the election by reducing taxes and increasing spending with the aim of increasing their probability to be re-elected.

\section{Methodology Research.}

In this research used secondary data. Secondary data is data collected from second-hand or from other sources that have been available before the study (Uber, 2015). Data obtained are included in the panel data group, ie, time series data that is the period of 2010 to 2014 as well as a cross-section of 456 areas of the population of 514 districts/cities in 34
Provinces in Indonesia, obtained a sample of 456 districts/cities from 33 provinces or the number of samples used as much as $88.72 \%$ of the population. 58 Districts/municipalities were excluded from this study because they were new autonomous regions (18 districts), areas with certain specialties (6 districts) and data from those areas were incompletely collected (34 districts).

To examine the impact of political proximity and the period of political office of the regional head on the allocation of local government spending, the mathematical function equation is used:

$$
\begin{aligned}
M O B E_{-} Y_{i t}=\alpha+ & \beta_{1} K D P O_{-} X 1_{i t}+\beta_{2} P J P O_{-} X 2_{i t} \\
& +\beta_{3} P K K O_{-} X 3_{i t}+\beta_{4} P L K O_{\_} X 4_{i t} \\
& +\beta_{5} A D K O_{-} X 5_{i t}+\beta_{6} J P K O_{-} X 6_{i t} \\
& +\mu_{i t}
\end{aligned}
$$

\begin{tabular}{|c|c|c|c|c|}
\hline No & Variable & $\begin{array}{l}\text { Symbols } \\
\end{array}$ & Definition Operational & Noted \\
\hline 1. & $\begin{array}{l}\text { Spend } \\
\text { Funding }\end{array}$ & $M O B E_{-} Y_{i t}$ & $\begin{array}{c}\text { Cost allocation of } \\
\text { Governments for } \\
\text { Development infrastructures } \\
\text { district }(\mathrm{Rp})\end{array}$ & $\begin{array}{l}\text { Data of real Funding Spend } \\
\text { (APBD) district Period 2010-2014 }\end{array}$ \\
\hline 2. & $\begin{array}{l}\text { Politics } \\
\text { Baseline }\end{array}$ & $K D P O_{-} X 1_{i t}$ & $\begin{array}{l}\text { Correlation parties between } \\
\text { Chairman and Parties } \\
\text { Majority on legislative } \\
\text { (Parties from head DPRD) }\end{array}$ & $\begin{array}{l}\text { Variable Dummy: } \\
1 \text {, Proximity Strong, if one party } \\
\text { supporting the Regional Head at } \\
\text { the time of nomination is the party } \\
\text { from the Chairman of the DPRD } \\
0 \text {, Proximity of Weak, if one of the } \\
\text { parties supporting the Regional } \\
\text { Head at the time of nomination is } \\
\text { not from the party from the } \\
\text { Chairman of DPRD }\end{array}$ \\
\hline 3. & $\begin{array}{l}\text { Period } \\
\text { Position of } \\
\text { Politic }\end{array}$ & $P J P O \_X 2_{i t}$ & $\begin{array}{c}\text { Periode Position head of } \\
\text { Regions (Regent and Mayor) }\end{array}$ & $\begin{array}{l}\text { Dummy Variable: } \\
\text { 1, The first period of office of the } \\
\text { regional head } \\
0 \text {, The second period of office of } \\
\text { the regional head. }\end{array}$ \\
\hline 4. & $\begin{array}{l}\text { Capita In } \\
\text { Come }\end{array}$ & $P K K O \_X 3_{i t}$ & $\begin{array}{c}\text { it Average community } \\
\text { income by region per year } \\
\text { (Rp/tahun) }\end{array}$ & Control Variable \\
\hline 5. & $\begin{array}{l}\text { Tenure of } \\
\text { land Kapita }\end{array}$ & $P L K O{ }_{-} X 4_{i t}$ & $\begin{array}{c}\text { it Average land area } \\
\text { controlled by population for } \\
\text { each region }\left(\mathrm{m}^{2} / \text { Peoples }\right)\end{array}$ & Control Variable \\
\hline 6 & $\begin{array}{l}\text { Apparatus } \\
\text { Region }\end{array}$ & $A D K O \_X 5_{i t}$ & $\begin{array}{c}\text { it Number of Civil State } \\
\text { Apparatus to local } \\
\text { government (people) }\end{array}$ & Control Variable \\
\hline 7. & Population & $J P K O \_X 6_{i t}$ & $\begin{array}{c}\text { Population in region } \\
\text { (Peoples) }\end{array}$ & Control Variable \\
\hline
\end{tabular}

Table 1: Definition of Operational Variable Research.

To estimate a regression model of panel data used three approaches are common effect model, fixed effect model, and random effect model. The three models of panel data regression estimation above can be selected depending on the number of analysis units and their research variables. However, there is a way that can be used to determine which technique is most appropriate in estimating panel data parameters. First, the Chow test is used to establish the Common Effect model or the Fixed Effect algorithm that is best used in estimating panel data. Second, the Hausman test used to choose between the Fixed Effect model or the most appropriate Random Effect model is used. Third, the Lagrange Multiplier (LM) test is used to select the Common Effect model or the Random Effect model. 
Classical assumption test consisting of multicollinearity test (using coefficient correlation Pearson), heteroscedasticity test (using White Heteroskedasticity Test) and autocorrelation test (using Durbin-Watson Test).

IV. The result of Research.

Modeling in using panel data regression techniques can use three alternative models produce the following information:

TABLE 2: VALUE OF REGRESI MODEL COMMON EFFECT, MODEL FIXED EFFECT AND MODEL RANDOM EFFECT

\begin{tabular}{|c|c|c|c|c|c|c|c|c|c|}
\hline \multirow{2}{*}{ Variables } & \multicolumn{3}{|c|}{ Common Effect } & \multicolumn{3}{|c|}{ Fixed Effect } & \multicolumn{3}{|c|}{ Random Effect } \\
\hline & Prob. & $R^{2}$ & $\begin{array}{c}\text { Dur } \\
\text { bin } \\
\text { wats } \\
\text { on }\end{array}$ & Prob. & $R^{2}$ & $\begin{array}{l}\text { Durbin } \\
\text { watson }\end{array}$ & Prob. & $R^{2}$ & $\begin{array}{c}\text { Durbin } \\
\text { Watson }\end{array}$ \\
\hline KDPO X1 & 0.0017 & \multirow{6}{*}{$\begin{array}{c}0.50 \\
8\end{array}$} & \multirow{6}{*}{$\begin{array}{c}1.05 \\
8\end{array}$} & 0.0040 & \multirow{6}{*}{0.830} & \multirow{6}{*}{1.992} & 0.0036 & \multirow{6}{*}{$\begin{array}{c}0.38 \\
4\end{array}$} & \multirow{6}{*}{1.637} \\
\hline $\begin{array}{l}\text { PJPO_X2 } \\
\end{array}$ & 0.2556 & & & 0.1866 & & & 0.2744 & & \\
\hline PKKO_X3 & 0.0000 & & & 0.0000 & & & 0.0000 & & \\
\hline PLKO X4 & 0.0000 & & & 0.0000 & & & 0.0000 & & \\
\hline ADKO X5 & 0.0000 & & & 0.0000 & & & 0.0000 & & \\
\hline JPKO X6 & 0.0000 & & & 0.0000 & & & 0.0000 & & \\
\hline
\end{tabular}

The principal of result regression of panel data with common effect model, fixed effect, and random effect model shows the coefficient of Independent variable KDPO_X1, PKKO_X3, PLKO_X4, ADKO_X5 and JPKO_X6 significant at $\alpha=0,05$ while PJPO_X2 is not significant at $\alpha=0,05$. The value of R2 and Durbin Watson in fixed effect model shows bigger numbers compared to common effect model and random effect model which means fixed effect model is good enough.

From the three models estimated will be selected which model is most appropriate/suitable for research by using chow test and Hausman test, with the result as follows:

\section{Chow Test}

Conducted to compare/choose which is best for common effect model and fixed effect model. The result of data panel estimation result through chow test can be seen in the following table:

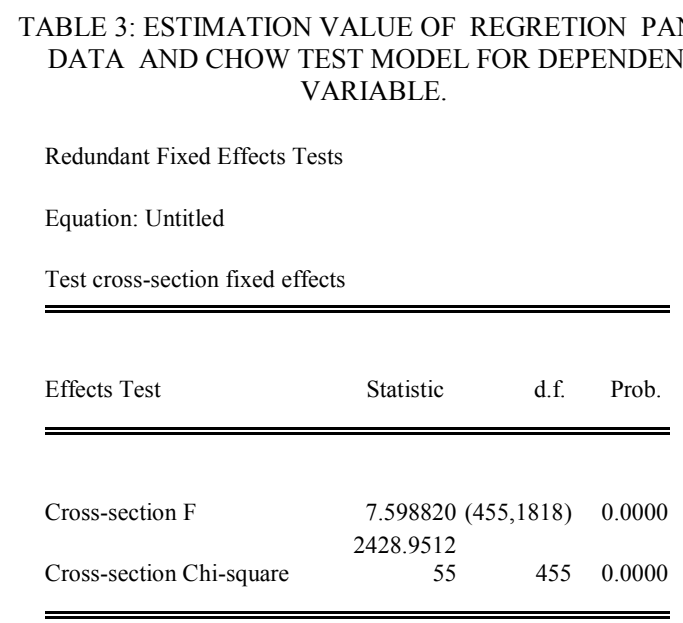

In the table above shows that the value Prob. Cross-Section of chi-square of 0.0000 whose value $<0.05$ so it can be concluded that the fixed effect model is more appropriate than the common effect model.

\section{Hausman test}

Hausman test is performed to compare/choose which model is best for fixed effect model and random effect model. The output of panel data estimation through Hausman test can be seen in the following table.

\section{TABLE 4 : VALUE ESTIMASI REGRESI DATA PANEL MODEL UJI-HAUSMAN FOR VARIABEL DEPENDEN SPEND}

Correlated Random Effects - Hausman Test

Equation: Untitled

Test cross-section random effects

\begin{tabular}{|c|c|c|c|}
\hline Test Summary & $\begin{array}{l}\text { Chi-Sq. } \\
\text { Statistic }\end{array}$ & Chi-Sq. d.f. & Prob. \\
\hline Cross-section random & 452.169449 & 6 & 0.0000 \\
\hline
\end{tabular}

In this tables above shows that the value Prob. A random cross-section of 0,0000 whose value $<0,05$ so it can be concluded that the fixed effect model is more appropriate than the random effect model. Results by Chow and Hausman Test which states that the selected design of the three possible models is the fixed effect model. 
TABLE 5 : VALUE ESTIMASI REGRESI DATA PANEL MODEL FIXED EFFECT FOR VARIABLE DEPENDENT SPEND MODAL

Dependent Variable: MOBE_Y

Method: Panel Least Squares

Sample: 20102014

Periods included: 5

Cross-sections included: 456

Total panel (balanced) observations: 2280

\begin{tabular}{ccccc}
\hline \hline & & & & \\
Variable & Coefficient & Std. Error & t-Statistic & Prob. \\
\hline \hline & & & & \\
C & -0.836087 & 2.713672 & -0.308102 & 0.7580 \\
KDPO_X1 & 0.080318 & 0.027906 & 2.878174 & 0.0040 \\
PJPO_X2 & 0.029897 & 0.022629 & 1.321153 & 0.1866 \\
PKKO_X3 & 0.949070 & 0.049139 & 19.31401 & 0.0000 \\
PLKO_X4 & -0.721742 & 0.116601 & -6.189842 & 0.0000 \\
ADKO_X5 & -1.698564 & 0.177630 & -9.562371 & 0.0000 \\
JPKO_X6 & 1.907300 & 0.164114 & 11.62180 & 0.0000 \\
\hline \hline
\end{tabular}

Effects Specification

\begin{tabular}{llll} 
Cross-section fixed (dummy variables) & & \\
\hline \hline & & & \\
R-squared & 0.830464 & Mean dependent var & 12.02663 \\
Adjusted R-squared & 0.787474 & S.D. dependent var & 0.632896 \\
S.E. of regression & 0.291769 & Akaike info criterion & 0.553113 \\
Sum squared resid & 154.7643 & Schwarz criterion & 1.714583 \\
Log-likelihood & -168.5488 & Hannan-Quinn criter. & 0.976758 \\
F-statistic & 19.31755 & Durbin-Watson stat & 1.992767 \\
Prob(F-statistic) & 0.000000 & & \\
\hline \hline
\end{tabular}

The fixed effect algorithm is still assumed to be a problem that may indicate the existence of multicollinearity and autocorrelation in the data because there is one independent variable that is not significant, i.e., the period of political office (PJPO_X2) with prob. 0.1866. Before the panel data regression model with fixed effect, model is used to conclude; the model must be tested first with classical assumption testing procedure and based on multicollinearity test, autocorrelation test and heteroscedasticity test show that the fixed effect model is free from classical hypothesis test.

Based on estimation method of Panel Least Squares with fixed effect model obtained by regression equation as follows:

MOBE_Y $=-0.836087+0.080318 *$ KDPO_X1
$0.029896 *$ PJPO_X2 $+0.949070 *$ PKKO_X 3
$0.721742 *$ PLKO_X4 $-1.698563 *$ ADKO_X5
$1.907300 * J P K O \_X 6+[\mathrm{CX}=\mathrm{F}]$

From the regression equation can be explained how the direction of influence between independent variables to the dependent variable, as described in the following table:

TABLE 6: DRIVING RELATIONSHIP BETWEEN INDEPENDENT VARIABLES AND CAPITAL EXPENDITURE VARIABLES

\begin{tabular}{|c|c|c|c|c|}
\hline No & VARIABIES & MOBE_Y & NOTES & SIGNIFICANTION \\
\hline 1. & KDPO_X1 & Positif & $\begin{array}{l}\text { The closer the relationship } \\
\text { between the legislature and } \\
\text { the executive will lead to } \\
\text { greater allocation of } \\
\text { regional apital } \\
\text { expenditures and vice } \\
\text { versa. }\end{array}$ & Significant \\
\hline 2. & PJPO_X2 & Positif & $\begin{array}{l}\text { The head of the first period } \\
\text { causes greater allocation of } \\
\text { regional capital } \\
\text { expenditures than the }\end{array}$ & Insignificant \\
\hline 3. & PKKO_X3 & Positif & The higher the per capita & Significant \\
\hline 4. & PLKO_X4 & Negatif & $\begin{array}{l}\text { The broader the per capita } \\
\text { community's land tenure, } \\
\text { the smaller the allocation of } \\
\text { regional capital expenditure }\end{array}$ & Significant \\
\hline 5. & ADKO_X5 & Negatif & $\begin{array}{l}\text { The more regional } \\
\text { apparatus will cause the } \\
\text { smaller allocation of } \\
\text { regional capital expenditure }\end{array}$ & Significant \\
\hline 6. & JPKO_X6 & Positif & $\begin{array}{l}\text { The greater the population } \\
\text { of the region will lead to } \\
\text { greater allocation of } \\
\text { regional capital expenditure }\end{array}$ & Significant \\
\hline
\end{tabular}

Based on the result of data processing with fixed effect model it is known that the political proximity significantly affects the allocation of capital expenditure with prob $=0.0000$. The slope of political proximity to the capital expenditure allocation is 0.080318 which means having a positive coefficient which can mean that the closer the political relationship between the legislature and the executive will lead to greater allocation of regional capital expenditure and the further the relationship between the legislature and the executive will encourage the allocation of capital expenditure the lower one.

Some reasons may be raised why political closeness between the executive and legislature causes a change in the distribution of capital investment:

a. The proximity between local legislative members and regional heads as chief executive leads to the decision-making process regarding budgeting easier to do without lengthy debates.

b. The proximity between the local legislative members and the director of the region leads both parties to be more accommodative in accepting proposals of development activities proposed by both sides to be incorporated into the APBD so that more and more proposed development plans will require larger budgets.

c. It is widely known that local spending for politicians to enrich themselves or groups by doing corruption. The proximity between legislative and executive members will then enlarge the allocation of 
capital expenditures so that the politicians can share the more "project rations" between them.

Based on the results of data processing with fixed effect model is known that the slope of the period of political office with capital expenditure worth 0.029896 which means to have a positive coefficient that can be interpreted that the head of the first period affect the increase in regional capital expenditure or vice versa chairman of the second term affect the decrease in local capital investment, but the influence of the period of political office to capital expenditure is not significant because it has a prob value above $5 \%$ is 0.1866 .

\section{Conclusions}

Based on the quantitative analysis results of the above, it can be concluded as follows:

1. Political proximity has a significant effect on changes in capital expenditure allocation and has a positive coefficient which means that the closer the political relationship between the legislature and the executive will lead to greater allocation of regional capital expenditures and the further the relationship between the legislature and the executive will encourage more capital expenditure allocation low,

2. Period of political office has no significant effect on capital expenditure changes

\section{REFERENCES}

Alesina, A. dan Drazen, A. 1991. Why are Stabilization Delayed ?. American Economic Review

Alesina, A. dan Waziarg. 1998. Economic Integrations and Political Disintegration. NBER

Drazen, A. dan Eslava, M. 2005. Electoral Manipulation Via Expenditure Composition: Theory And Evidence. NBER

Dash, Bharatee Bhusana. Dan Raja, Angara V. 2012. Political Determinants Of The Allocation Of Public Expenditure: A Study Of Indian States. Universities of Aachen.

Foucault, Martial; et al. 2008. Public Spending Interaction And Local Politics. Empirical Evidence From French Municipalities.

Galli, Emma. Dan Rossi, Stefania Ps. 2002 Political Budget Cycles: The Case Of The Western German Lander. ProQuest Sociology.

Kaushik, Arum dan Pal, Rupayan. 2012. Political Stronghold And Budget Allocation For Developmental Expenditure: Evidence From Indian States 1971 - 2005. National Institute of Public Finance New Delhi

Rogoff, K. 1990. Equilibrium Political Budget Cycles. American economic review
Rogoff, K. dan Sibert A. 1988. Election and Macroeconomic Cycle. review of economics studies

Roubini N dan Sachs J. 1989. Political and Economic Determinants of Budget Deficit in the Industrial Economies, NBER

Sole-Sole, Albert. 2006. The Effects Of Party Competition On Budget Outcomes: Empirical Evidence From Local Governments In Spain; Springer. 